Diabetologia 1, 731-742 (1974)

(c) by Springer-Verlag 1974

\title{
Enzymes of Carbohydrate and Fat Metabolism in Anti-Insulin Serum Diabetes; Inactivation by Free Fatty Acids and the Protective Effect of Cellular Protein
}

\author{
E. Shafrir and N.B. Ruderman \\ Department of Biochemistry, Hebrew University-Hadassah Medical School, Jerusalem, Israel and Joslin Research \\ Laboratory, Department of Medicine, Harvard Medical School, Boston, Massachusetts, USA
}

Received: April 11, 1974 and in revised form: July 8, 1974

Summary. The possibility that free fatty acids (FFA) and their CoA esters may directly inhibit the activity of enzymes of glycolysis and lipogenesis was studied in liver and adipose tissue of acutely diabetic rats. Despite a marked elevation in tissue FFA, the activity of glucose-6phosphate dehydrogenase, phosphofructokinase, pyruvate kinase, $\alpha$-glycerophosphate dehydrogenase, aldolase, citrate synthetase, and several other enzymes was not affected 3 or $6 \mathrm{~h}$ after anti-insulin serum injection. The activities of hepatic and adipose tissue acetyl-CoA carboxylase, hepatic glucokinase and adipose tissue hexokinase were decreased. The tissue FFA levels were compared to linoleate concentrations required for halfmaximal inhibition $\left(\mathbf{K}_{\mathbf{i}}\right)$ of several enzymes in tissue fractions after in vitro contact of $30 \mathrm{~min}$ at $37^{\circ} \mathrm{C}$. Linoleate irreversibly inactivated the enzymes to a varying degree but its effect was dependent on the protein content of the system. The $K_{\mathbf{i}}$ of linoleate increased linearly with cellular protein concentration; when extrapolated to the protein level in the intact cell it became unphysiologically high, markedly exceeding the liver or adipose tissue FFA concentration of acutely diabetic rats. The $K_{i}$ linoleate and the actual FFA concentrations were particularly discrepant in the cytoplasmic compartment, comprising most of the investigated enzymes, but only a small proportion of tissue FFA, as determined by measurements of intracellular FFA distribution. Similar discrepancy was found for the interaction of palmityl-CoA with glucose-6-phosphate dehydrogenase and acetyl-CoA carboxylase. Thus, the selective decrease in the activity of glucokinase and acetyl-CoA carboxylase in acute diabetes was attributed to factors other than FFA or their CoA esters. The nature of FFA-enzyme interaction, causing enzyme inactivation rather than specific inhibition is discussed, concluding that FFA do not act as direct homeostatic modifiers of enzymes regulating carbohydrate and fat metabolism.

Key words: Free fatty acids; fatty acid-CoA esters; enzymes; glycolysis; lipogenesis; anti-insulin serum; liver; adipose tissue.
Several reports have appeared in recent years indicating that long-chain free fatty acids (FFA) and $\mathrm{CoA}$ esters of long-chain fatty acids directly alter the activity of various enzymes of glucose metabolism and lipogenesis. The activities of glucokinase, hexokinase, phosphofructokinase, pyruvate kinase, glucose-6-phosphate dehydrogenase $[26,54]$ acetyl-CoA carboxylase $[25]$ and $\alpha$-glycerophosphate dehydrogenase [53] were reduced after in vitro incubation of dilute rat liver homogenate fractions or purified enzyme preparations with FFA. In similar experiments, the CoA esters of long chain fatty acids have been demonstrated to inhibit the activity of acetyl-CoA carboxylase [5], citrate synthetase $[44,55]$ glucose-6-phosphate dehydrogenase [17], phosphatidic acid phosphatase [6], glucokinase [12], fatty acid synthetase [16] and pyruvate and ketoglutarate dehydrogenases [18].

Since the circulating and the intracellular concentrations of FFA rise in starvation and diabetes, when glycolysis is inhibited and gluconeogenesis promoted, it has thus been suggested that FFA may have a physiological role in effecting the switchover from glucose consumption to glucose production $[26,54]$. Likewise, both FFA and fatty acyl CoA esters have been implicated to be instrumental in curtailing lipogenesis $[5,25]$.
On the other hand, doubts have been raised whether FFA may serve as selective modifiers of enzyme activity of physiological relevance, because the interaction of enzymes with FFA or their CoA derivatives is based on a rather poorly defined association at a high molar ratio of FFA to the enzymes. Moreover, FFA were found to irreversibly inactivate numerous enzymes without obvious structural or functional relationship [44, 16, 33, 38, 47].

It was our purpose to assess the importance of inactivation of enzymes by FFA and their CoA derivatives under the condition of rapidly elevated cellular FFA concentrations elicited by the injection of anti-insulin serum. To evaluate the in vivo FFAenzyme interaction, inactivation of enzymes was also studied after contact of cellular fractions with FFA in vitro. To approach the situation in the intact cell, special attention was given to the role of protein presence during the FFA-enzyme interaction, since the extent of FFA binding to specific enzymes in a mixture like tissue cytoplasm is influenced by the presence of other proteins with competing affinity for FFA.

The results demonstrated a highly protective effect of cellular proteins of the liver or adipose tissue on enzyme activity, and indicated that the FFA 
concentrations in the cytoplasm are too low to cause substantial enzyme inactivation, even when elevated as a result of extensive lipolysis. These findings do not support the contention that major physiological adjustments are effected by direct interaction of enzymes with FFA. Some of these results were reported previously in a preliminary form [38, 39].

\section{Materials and Methods}

\section{Homogenate Preparation}

Male Sprague-Dawley rats, weighing 200 to $250 \mathrm{~g}$, maintained on Purina laboratory chow, were decapitated and bled. Liver homogenates $(33 \%, W / V)$ were prepared at $4^{\circ} \mathrm{C}$ in a coaxial glass homogenizer equipped with a Teflon pestle. Epididymal adipose tissue was homogenized at room temperature in an all-glass Tenbroeck hand homogenizer and chilled afterwards. For most enzyme activity determinations the homogenizing solution used was $0.2 \mathrm{M}$ sucrose, containing $20 \mathrm{mM}$ triethanolamine-HCl, pH 7.5, $1 \mathrm{mM} \mathrm{Na}$ EDTA and $1 \mathrm{mM}$ glutathione. For the determination of glucokinase and hexokinase, the homogenizing solution was $0.15 \mathrm{M} \mathrm{KCl}$ and for phosphofructokinase, $0.2 \mathrm{M}$ sucrose containing $50 \mathrm{mM} \mathrm{KF}$.

The cytoplasmic fraction was obtained by centrifugation at $100000 \mathrm{~g}$ for $45 \mathrm{~min}$. For the isolation of the mitochondrial fraction, the homogenate was first centrifuged for $5 \mathrm{~min}$ at $800 \mathrm{~g}$ to remove the debris, and the supernatant fluid was then recentrifuged for $10 \mathrm{~min}$ at $12000 \mathrm{~g}$. The precipitate was washed with the homogenizing solution, lyophylized and stored at $-20^{\circ} \mathrm{C}$ until use.

\section{Enzyme-Linoleate Interaction}

For the study of in vitro interaction of FFA with enzymes, linoleate (Hormel Institute of the University of Minnesota, U.S.A.) was chosen as the representative long-chain FFA because of the relative ease with which concentrated aqueous stock solutions could be prepared at $\mathrm{pH} 8.0$ to 8.5 . Sets of tubes were prepared on an ice bath, each containing the cytoplasmic fraction at a constant protein concentration within the range of 40 to $1 \mathrm{mg} / \mathrm{ml}$. The dilution was made with the original homogenizing solution. A stock solution of potassium linoleate was added to produce a series with decreasing linoleate/protein ratios. Final concentrations of linoleate in each set with a constant protein concentration were 0.1 to $14 \mu$ moles $/ \mathrm{ml}$. The volume ratio of the cytoplasmic fraction to the linoleate solution (or water blank) was 4:1, and the final $\mathrm{pH}$ was 7.5 to 7.6. After the addition of linoleate, nitrogen was gently passed through the tubes, to prevent oxidation, the tubes were covered with parafilm and incubated for $30 \mathrm{~min}$ on a water bath at $37^{\circ} \mathrm{C}$. The activity of various enzymes was then promptly determined, the tubes being stored on ice up to the assay. To obtain a sample at concentration convenient for the assay of enzyme activity, when necessary, the mixture was diluted with a $1 \%$ solution of bovine FFA-poor albumin (Pentex Co., Kankakee, Ill., U.S.A.) in a buffer appropriate for the assay.

\section{Enzyme Assays}

Enzyme assays, based on NADH/NAD interconversion, were performed by recording the changes in fluorescence in an AMINCO microfluorometer. Standard spectrophotometric procedures were adapted for this purpose. Sensitivity was adjusted so that 5 to $10 \mathrm{nmole} / \mathrm{ml}$ of the reduced nucleotide produced a full scale deflection.

The methods used were as follows: aldolase, EC 4.1.2.13, [42]; glucokinase and hexokinase, EC 2.7.1.2 and $\mathrm{EC}$ 2.7.1.1. respectively, [40]; phosphofructokinase, EC 2.7.1.11, [50]; $\alpha$-glycerophosphate dehydrogenase, EC 1.1.99.5, [2]; pyruvate kinase, EC 2.7.1.40 [7]; NAD-malate dehydrogenase, EC 1.1.1.37, [32]; NADP-malate dehydrogenase ("malate enzyme") EC 1.1.1.40 and NADP-isocitrate dehydrogenase, EC 1.1.1.42, [31]; ATP-citrate lyase ("citrate cleavage enzyme"), EC 4.1.3.8, [43] and glucose-6-phosphate dehydrogenase, EC 1.1.1.49, [19]. Glucose-6-phosphatase, EC 3.1.3.9, [46] was determined in a crude liver homogenate.

The activity of acetyl-CoA carboxylase, EC 6.4.1.2, was determined by fixation of $\mathrm{KH}^{14} \mathrm{CO}_{3}$ at $15 \mathrm{mM}$ concentration by a procedure adapted from Matsuhashi et al. [28]. The enzyme was activated by $30 \mathrm{~min}$ pre-incubation with $15 \mathrm{mM}$ citrate at $30^{\circ} \mathrm{C}$. Activity of acetyl-CoA carboxylase was also measured by incorporation of $2,5-{ }^{14} \mathrm{C}$-citrate into fatty acids without preactivation [41].

Phosphoenolpyruvate carboxylase, EC 4.1.1.32, was determined by fixation of $\mathrm{KH}^{14} \mathrm{CO}_{3}$ in the presence of IDP [10].

Citrate synthetase ("citrate condensing enzyme"), EC 4.1.3.7, was determined spectrophotometrically [30], and pyruvate carboxylase, EC 6.4.1.1. by a radiochemical assay [51], both in lyophylized mitochondria, reconstituted in the original homogenizing solution.

All activities were measured at $30^{\circ} \mathrm{C}$ and expressed as nmoles of substrate metabolized per min per $\mathrm{mg}$ protein in the respective cellular fraction. The activity remaining after in vitro contact with linoleate was expressed as percentage of the activity measured in the same fraction after incubation in the absence of linoleate. Protein content was determined by a modification of the method of Lowry et al. [27].

The auxiliary enzymes and substrates were purchased from Sigma Chemical Co., U.S.A. or Boehringer GmbH, Germany. Acetyl-CoA and palmityl-CoA were obtained from P-L Laboratories, Milwaukee, Wisc., U.S.A. Radioactive materials were purchased from the New England Nuclear Corporation. 


\section{Anti-Insulin Serum Injection}

Guinea pig anti-insulin serum was injected into the rat femoral vein, under light $\mathrm{CO}_{2}: \mathrm{O}_{2}$ anesthesia. The anti-insulin serum was injected in two doses of 3.5 units each, at $90 \mathrm{~min}$ intervals to rats fed ad libitum or in three doses of 3.5 units each, at the same intervals to $24 \mathrm{hrs}$ fasted rats. Control animals received normal guinea pig serum according to the same schedule. The animals were killed by decapitation $3 \mathrm{hrs}$ (fed rats), or $6 \mathrm{hrs}$ (fasted rats), after the initial injection.

\section{Determination of Tissue FFA Content and Distribution}

To prevent lipolysis di-isopropyl fluorophosphate (DFP), in final concentration of $0.1 \mathrm{mM}$, was added to portions of the liver and adipose tissue homogenates. As a marker of FFA, $0.1 \mu \mathrm{c}$ of $1 .{ }^{14} \mathrm{C}$-oleate was added in trace amount. A sample of the homogenate was then extracted with Dole's mixture [14]. The rest was centrifuged to separate mitochondrial $(10 \mathrm{~min}$ at $12000 \mathrm{~g}$ ), microsomal (45 min at $100000 \mathrm{~g}$ ) and cytoplasmic fractions. These fractions were quantitatively collected and extracted. In the case of adipose tissue, the mitochondrial and microsomal fractions were separated together at $100000 \mathrm{~g}$. The fat layer at the top of the tube was also transferred to the Dole's extractant.

The phases in the extract were separated by the addition of appropriate amounts of water and heptane within 15 to $30 \mathrm{~min}$ to avoid an increase in titratable acidity in stored tissue extracts. The upper heptane layer was twice washed on a synthetic lower phase of acidic isopropanol and water [14]. Next, it was transferred to a double volume of $0.05 \mathrm{~N} \mathrm{KOH}$ solution in $50 \%$ ethanol for the separation of FFA. The FFA were then reextracted into a fresh portion of heptane by acidification of the alkaline ethanolic phase and finally titrated and counted. The absence of phospholipids and neutral lipids in the final FFA extracts was verified by thin layer chromatography. For the titration of FFA in the cytoplasmic fraction of liver it was necessary to concentrate the extract 3 to 4 fold by evaporation under nitrogen. The concentration of FFA in the cytoplasmic fraction of adipose tissue was too low for titration. The percent distribution of FFA in this fraction only was determined by radioactivity. The extraction and separation of tissue FFA was monitored by processing, in parallel, a labeled standard. The losses amounted from 10 to $15 \%$ of the starting amount and the tabulated values were corrected accordingly.

\section{Results}

\section{In Vivo Experiments}

To determine if a rapid increase in intracellular EFA will induce a reduction in the activity of cytoplasmic and mitochondrial enzymes related to carbohydrate and fat metabolism, acute diabetes was produced by the injection of anti-insulin serum. The changes in net serum glucose and FFA levels are recorded in Table 1. Glucose levels rose 2.5 to 3 -fold in both the fed and fasted rats. The extent of serum FFA rise was larger in the fed than in the fasted rats, but highest FFA levels were obtained in the fasted animals.

Table 1. Effect of anti-insulin serum on serum $F F A$ and glucose levels

Values are means $\pm S E$ for the number of rats indicated in parentheses. For injection schedule see Methods.

\begin{tabular}{lcc}
\hline & $\begin{array}{l}\text { Serum } \\
\text { Glucose } \\
\text { mg/100 ml }\end{array}$ & $\begin{array}{l}\text { Serum } \\
\text { FFA } \\
\mu \mathrm{Eq} / \mathrm{ml}\end{array}$ \\
\hline Fed rats & & \\
$\quad$ Control (5) & $133 \pm 5$ & $0.35 \pm 0.04$ \\
Anti-insulin serum (5) & $332 \pm 30$ & $1.14 \pm 0.06$ \\
24 hrs fasted rats & $96 \pm 3$ & $0.61 \pm 0.03$ \\
Control (4) & $291 \pm 25$ & $1.27 \pm 0.11$ \\
\hline Anti-insulin serum (7) & 29 \\
\hline
\end{tabular}

The FFA content and distribution in liver and adipose tissue are presented in Tables 2 and 3 respectively. The total FFA levels found in liver and adipose tissue are within the range of previously reported values of 0.3 to $2.8 \mu$ moles/g for liver $[22,35,48]$ and 1 to 3 moles for adipose tissue [23, 48, 52], as dertermined by various methods. As far as the distribution of FFA is concerned, most of the FFA in the normal liver were bound to subcellular particles; only about $6 \%$ of the total FFA resided in the cytoplasmic fraction. Of the particle fractions, the mitochondria appeared to bind somewhat more FFA than the microsomes. On the other hand, the microsomal protein content was less than one half that of the mitochondrial fraction; therefore, the microsomes exhibited a higher binding affinity for FFA per $\mathrm{mg}$ of protein. This is in agreement with the report of Reshef and Shapiro [34] who demonstrated a marked binding capacity of subcellular particles of liver and adipose tissue for FFA in vitro. Upon injection of antr-insulin serum, the total liver FFA content rose 80 to $90 \%$ in both the fed and fasted rats, but the distribution of FFA among the subcellular fractions did not change appreciably. The concentration of FFA in the cytoplasmic fraction rose twofold approximately, to $0.3 \mathrm{mM}$ and $0.7 \mathrm{mM}$, in the fed and fasted rats respectively.

In adipose tissue, the compartment in which the highest proportion of FFA was recovered was the fat layer (Table 3). This compartment constituted about $85 \%$ of adipose tissue wet weight and contained about $70 \%$ of the total FFA content. Approximately $30 \%$ of the total FFA was found in the particle fractions and only $1 \%$ in the soluble fraction representing the cytoplasm. To calculate the FFA concentration in the latter fraction an assumption was made that the cytoplasmic and the intercellular water spaces together comprise $10 \%$ of adipose tissue volume [11] and that the FFA concentration in these two compartments is 
similar. The value obtained was approximately $0.3 \mathrm{mM}$ in normal fed rats.

The subcellular distribution of FFA in adipose tissue did not change appreciably as a result of antiinsulin serum injection, although the total tissue FFA content increased by about $190 \%$ in fed rats and by about $40 \%$ in fasted rats. The FFA concentration in the eytoplasmic fraction of adipose tissue was estimated to rise, after the injection of anti-insulin serum, to $1.1 \mathrm{mM}$ in the fed rats and $2.1 \mathrm{mM}$ in fasted rats. were seen when its activity was dertemined by citrate incorporation into fatty acids than by $\mathrm{CO}_{2}$ fixation. Apart from these changes, there were no significant decreases in the activity of any of the other enzymes studied. Conversely, there were significant increases in the activity of the gluconeogenic enzymes pyruvate carboxylase and phosphoenolpyruvate carboxylase.

In adipose tissue, a decrease in the activity of hexokinase was observed which was significant only in the fasted rats injected with anti-insulin serum

Table 2. FFA content and distribution in liver of rats injected with anti-insulin serum

The values given are means $\pm S E$ for the number of rats indicated in parentheses. AIS $=$ anti-insulin serum.

The levels of total liver FFA were determined by titration as described in the methods. The distribution of FFA was determined from the distribution of added ${ }^{1-14} \mathrm{C}$-oleate and by titration of FFA in the separated fractions. The combined recovery of FFA from the subcellular fractions obtained by titration exceeded the FFA content of the original homogenate by 9 to $20 \%$. The combined recovery of oleate radioactivity was 89 to $93 \%$. The distribution values obtained by the titration and radioactivity methods agreed within 8 to $14 \%$. The values listed in the Table are those of $1 .{ }^{14} \mathrm{C}$-oleate distribution. In the case of the cytoplasmic fraction the values of both the distribution and actual titration are given.

Mean liver protein distribution was: mitochondrial 47 , microsomes 19 , and cytoplasm $72 \mathrm{mg} / \mathrm{g}$.

\begin{tabular}{|c|c|c|c|c|}
\hline Fraction & $\begin{array}{l}\text { Fed } \\
(5)\end{array}$ & $\begin{array}{l}\text { Fed }+ \text { ATS } \\
\text { (5) }\end{array}$ & $\begin{array}{l}\text { Fasted } \\
\text { (4) }\end{array}$ & $\begin{array}{l}\text { Fasted + } \\
\text { AIS } \\
(7)\end{array}$ \\
\hline Total FFA, $\mu$ moles/g & $1.64 \pm 0.14$ & $3.10 \pm 0.37$ & $4.04 \pm 0.62$ & $7.17 \pm 0.65$ \\
\hline $\begin{array}{l}\text { Mitochondria, \% } \\
\text { Microsomes, \% } \\
\text { Cytoplasm, \% }\end{array}$ & $\begin{array}{r}51.4 \pm 4.5 \\
42.4 \pm 3.9 \\
6.2 \pm 0.6\end{array}$ & $\begin{array}{r}49.0 \pm 5.1 \\
43.3 \pm 4.4 \\
7.7 \pm 1.2\end{array}$ & $\begin{array}{r}54.5 \pm 6.5 \\
37.7 \pm 4.3 \\
7.8 \pm 1.0\end{array}$ & $\begin{array}{r}51.9 \pm 4.8 \\
39.0 \pm 4.5 \\
9.1 \pm 1.6\end{array}$ \\
\hline Cytoplasm, $\mu$ moles $/ \mathrm{ml}$ & $0.12 \pm 0.02$ & $0.28 \pm 0.03$ & $0.34 \pm 0.05$ & $0.74 \pm 0.06$ \\
\hline
\end{tabular}

Table 3. FFA content and distribution in adipose tissue of rats injected with antiinsulin serum

Values given are means \pm SE for the number of rats indicated in parentheses.

The levels of total adipose tissue FFA and the FFA distribution were determined as described in Table 2 for the liver. Recovery values were similar. The values listed in the Table are those of $\mathbf{1 -}^{14} \mathrm{C}$-oleate distribution. Because of considerable dilution, the FFA levels in the cytoplasmic fraction were too low for titration. The cytoplasmic FFA concentration was calculated from the mean total FFA level and percent of $1{ }^{14} \mathrm{C}$-oleate radioactivity in this fraction. An assumption was made that the aqueous portion of adipose tissue is $100 \mu \mathrm{\mu l} / \mathrm{g}$ [11] and that the FFA in the intracellular and extracellular water space are the same.

The mean concentrations of protein in the fractions were: mitochondria + microsomes, 3.9 ; cytoplasmic fraction, 7.3 ; and fat (layer), $0.3 \mathrm{mg} / \mathrm{g}$.

\begin{tabular}{|c|c|c|c|c|}
\hline$\overline{\text { Fraction }}$ & $\begin{array}{l}\text { Fed } \\
(5)\end{array}$ & $\begin{array}{l}\text { Fed + AIS } \\
(5)\end{array}$ & $\begin{array}{l}\text { Fasted } \\
(4)\end{array}$ & $\begin{array}{l}\text { Fasted + AIS } \\
\text { (7) }\end{array}$ \\
\hline 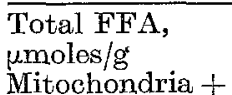 & $2.32 \pm 0.20$ & $6.70 \pm 0.62$ & $7.31 \pm 0.78$ & $10.54 \pm 0.85$ \\
\hline microsomes, \% & $29.0+1.9$ & $27.8+3.8$ & $26.4 \pm 3.0$ & $31.1 \pm 1.3$ \\
\hline Fat layer, \% & $70.0 \pm 6.1$ & $70.1 \pm 7.8$ & $72.2 \pm 8.4$ & $67.1 \pm 5.6$ \\
\hline Cytoplasm, \% & $1.0 \pm 0.1$ & $1.5 \pm 0.1$ & $1.3 \pm 0.2$ & $1.8 \pm 0.2$ \\
\hline $\begin{array}{l}\text { Cytoplasm, } \\
\text { umoles/ml }\end{array}$ & 0.26 & 1.12 & 1.09 & 2.11 \\
\hline
\end{tabular}

The activity of enzymes in the liver of rats injected with anti-insulin serum is listed in Table 4 . The activity of glucokinase decreased slightly, though significantly as found previously in similar experiments [37]. The activity of acetyl-CoA carboxylase also decreased, in agreement with the findings of Kalkhoff and Kipnis [22]. Larger decreases in acetyl-CoA carboxylase
(Table 5). Acetyl-CoA carboxylase activity, measured by $\mathrm{CO}_{2}$ fixation, decreased both in the fed and fasted rats. The activities of other enzymes related to glycolysis and lipogenesis did not change significantly. In contrast, the activity of phosphoenolpyruvate carboxylase, which in adipose tissue is an important regulatory enzyme for glyceroneogenesis 
$[1,21]$ increased significantly after anti-insulin serum injection both in the fed and fasted rats.

\section{In Vitro Experiments}

To obtain an estimate of FFA concentrations, which would be required to produce significant enzyme activity reduction under conditions simulating the cellular millieu, the cytoplasmic fraction of liver and adipose tissue were brought in contact with linoleate. The activity of enzymes was determined after $30 \mathrm{~min}$ of ineubation at varying cytoplasmic protein/linoleate concentration ratios. Plots of enzyme activity versus linoleate concentration were constructed for each of a series of protein concentrations, from which the linoleate concentration required for halfmaximal enzyme activity reduction $\left(K_{i}\right)$ was read. This is illustrated in Fig. 1 for the hepatic glucose-6phosphate dehydrogenase.

It is evident from the figure that at higher soncentrations of protein, higher concentrations of linoleate were required to decrease the activity of the enzyme. The $K_{i}$ of linoleate for glucose-6-phosphate dehydrogenase increased about 20 -fold (from 0.12 to $25 \mathrm{mM}$ ) when the protein concentration was increased by a

Table 4. Liver enzyme activities after anti-insulin serum injection

Values are means $\pm \mathrm{SE}$; number of rats in each group indicated in parentheses. AIS = anti-insulin serum

\begin{tabular}{|c|c|c|c|c|}
\hline \multirow[t]{2}{*}{ Enzyme } & \multicolumn{4}{|c|}{ Activity, nmoles/min per mg protein } \\
\hline & $\begin{array}{l}\text { Fed } \\
(5)\end{array}$ & $\begin{array}{l}\text { Fed + ATS } \\
\text { (5) }\end{array}$ & $\begin{array}{l}\text { Fasted } \\
(4)\end{array}$ & $\begin{array}{l}\text { Fasted + AIf } \\
\text { (7) }\end{array}$ \\
\hline \multicolumn{5}{|c|}{ Glycolysis and lipogenesis } \\
\hline Glucokinase & $25.9 \pm 1.0$ & $17.6 \pm 1.8^{\mathrm{c}}$ & - & - \\
\hline Hexolzinase & $3.4 \pm 0.4$ & $4.3 \pm 0.4$ & - & - \\
\hline Phosphofructokinase & $13.6+0.8$ & $13.2+1.2$ & $12.8+1.6$ & $12.0+1.0$ \\
\hline Aldolase & $136 \pm 16$ & $145 \pm 19$ & $119 \pm 14$ & $111 \pm 11$ \\
\hline Pyruvate kinase & $495 \pm 21$ & $461 \pm 12$ & $442 \pm 25$ & $417 \pm 29$ \\
\hline$\alpha$-glycerophosphate dehydrogenase & $477 \pm 53$ & $416 \pm 39$ & $523 \pm 43$ & $468 \pm 20$ \\
\hline Glucose-6-phosphate dehydrogenase & $29.5+1.7$ & $26.5 \pm 1.0$ & $24.5+2.2$ & $25.8+1.9$ \\
\hline 6-phosphogluconate dehydrogenase & $55.8 \pm 2.4$ & $55.4 \pm 3.4$ & $48.3 \pm 3.1$ & $46.9 \pm 2.2$ \\
\hline Lactate dehydrogenase & $3580 \pm 150$ & $3740 \pm 120$ & $3910 \pm 130$ & $4290 \pm 210$ \\
\hline NADP-malate dehydrogenase & $43.2 \pm 2.8$ & $42.8 \pm 5.4$ & $34.6 \pm 2.2$ & $28.0 \pm 3.6$ \\
\hline ATP-citrate lyase & $25.2 \pm 1.4$ & $24.0 \pm 2.2$ & $18.4 \pm 1.2$ & $15.8 \pm 1.4$ \\
\hline \multicolumn{5}{|l|}{ Acetyl-CoA carboxylase } \\
\hline by $\mathrm{CO}_{2}$ fixation & $3.6 \pm 0.2$ & $2.8 \pm 0.3$ & $2.3 \pm 0.2$ & $1.6 \pm 0.2^{\mathrm{c}}$ \\
\hline by citrate incorporation & $1.23 \pm 0.07$ & $0.27 \pm 0.06^{\mathrm{c}}$ & $0.29 \pm 0.03$ & $0.09 \pm 0.02^{\mathrm{c}}$ \\
\hline \multicolumn{5}{|c|}{ Gluconeogenesis and tricarboxylic acid cycle } \\
\hline Glucose-6-phosphatase ${ }^{a}$ & $67.2 \pm 5.1$ & $74.3 \pm 8.4$ & $84 \pm 7.3$ & $96 \pm 6.5$ \\
\hline Pyruvate carboxylaseb & $58.2 \pm 6.1$ & $63.5 \pm 5.4$ & $93 \pm 8$ & $124 \pm 9 c$ \\
\hline Phosphoenolpyruvate carboxylase & $62.3 \pm 3.6$ & $89.6 \pm 9.2^{\mathrm{c}}$ & $121 \pm 9$ & $159 \pm 10^{\mathrm{c}}$ \\
\hline Aspartate aminotransferase & $379 \pm 13$ & $447 \pm 30$ & $494 \pm 42$ & $597 \pm 57$ \\
\hline NADP-isocitrate dehydrogenase & $245 \pm 10$ & $273 \pm 13$ & $249 \pm 6$ & $221 \pm 11$ \\
\hline Citrate synthetase ${ }^{b}$ & $23.5 \pm 1.0$ & $24.7 \pm 1.7$ & $25.2 \pm 1.9$ & $23.9 \pm 1.8$ \\
\hline
\end{tabular}

a Activity expressed per $\mathrm{mg}$ protein in the crude homogenate

$\mathrm{b}$ Activity expressed per $\mathrm{mg}$ of mitochondrial protein

c Difference from control rats significant at $P<0.05$ at least

Table 5. Adipose tissue enzyme activities after anti-insulin serum injection

Values are means $\pm \mathrm{SE}$ : number of rats in each group indicated in parentheses. AIS = anti-insulin serum.

\begin{tabular}{|c|c|c|c|c|}
\hline \multirow[b]{2}{*}{ Enzyme } & \multicolumn{4}{|c|}{ Activity, nmoles/min per mg protein } \\
\hline & $\begin{array}{l}\text { Fed } \\
(5)\end{array}$ & $\begin{array}{l}\text { Fed }+ \text { AIS } \\
(5)\end{array}$ & $\begin{array}{l}\text { Fasted } \\
(4)\end{array}$ & $\begin{array}{l}\text { Fasted + AIS } \\
(7)\end{array}$ \\
\hline \multicolumn{5}{|c|}{ Glycolysis and lipogenesis } \\
\hline Hexokinase & $14.8 \pm 1.5$ & $12.6 \pm 1.0$ & $13.1 \pm 1.2$ & $9.1 \pm 0.8^{a}$ \\
\hline Pyruvate kinase & $162 \pm 9$ & $157 \pm 13$ & $187 \pm 11$ & $171 \pm 14$ \\
\hline$\alpha$-glycerophosphate dehydrogenase & $121 \pm 6$ & $108 \pm 6$ & $112 \pm 8$ & $99 \pm 5$ \\
\hline Glucose-6-phosphate dehydrogenase & $55.7 \pm 3.3$ & $47.5 \pm 3.6$ & $44.2 \pm 2.0$ & $38.0 \pm 3.2$ \\
\hline 6-phosphogluconate dehydrogenase & $28.6 \pm 5.4$ & $21.2 \pm 2.9$ & - & \pm \\
\hline Lactate dehydrogenase & $985 \pm 35$ & $1022 \pm 109$ & $960 \pm 129$ & $1035 \pm 78$ \\
\hline NADP-malate dehydrogenase & $86.2 \pm 7.4$ & $81.4 \pm 9.2$ & $71.6 \pm 4.4$ & $60.8 \pm 5.2$ \\
\hline \multirow{2}{*}{\multicolumn{5}{|c|}{ Acetyl-CoA carboxylase }} \\
\hline & & & & \\
\hline Phosphoenolpyruvate carboxylase & $8.5 \pm 0.5$ & $12.8+1.2^{\mathrm{a}}$ & $\begin{array}{r}0.0 \pm 0.3 \\
21.2 \pm 1.3\end{array}$ & $\begin{array}{r}2.0 \pm 0.0^{\mathrm{a}} \\
28.6+1.9^{\mathrm{a}}\end{array}$ \\
\hline Aspartate amino-transferase & $67.6 \pm 5.8$ & $77.2 \pm 5.7$ & $84.8 \pm 9.5$ & $93.8 \pm 13.2$ \\
\hline NADP-isocitrate dehydrogenase & $76.8 \pm 5.4$ & $73.4 \pm 4.1$ & $64.5 \pm 8.4$ & $48.8 \pm 6.1$ \\
\hline
\end{tabular}

a Difference from control rats significant at $P>0.05$ at least 
similar factor (from 0.15 to $36 \mathrm{mg} / \mathrm{ml}$ ). This was the highest cytoplasmic protein concentration attainable in our in vitro experimental setup, and represented a 3 to 4 -fold dilution of the original cytoplasm.
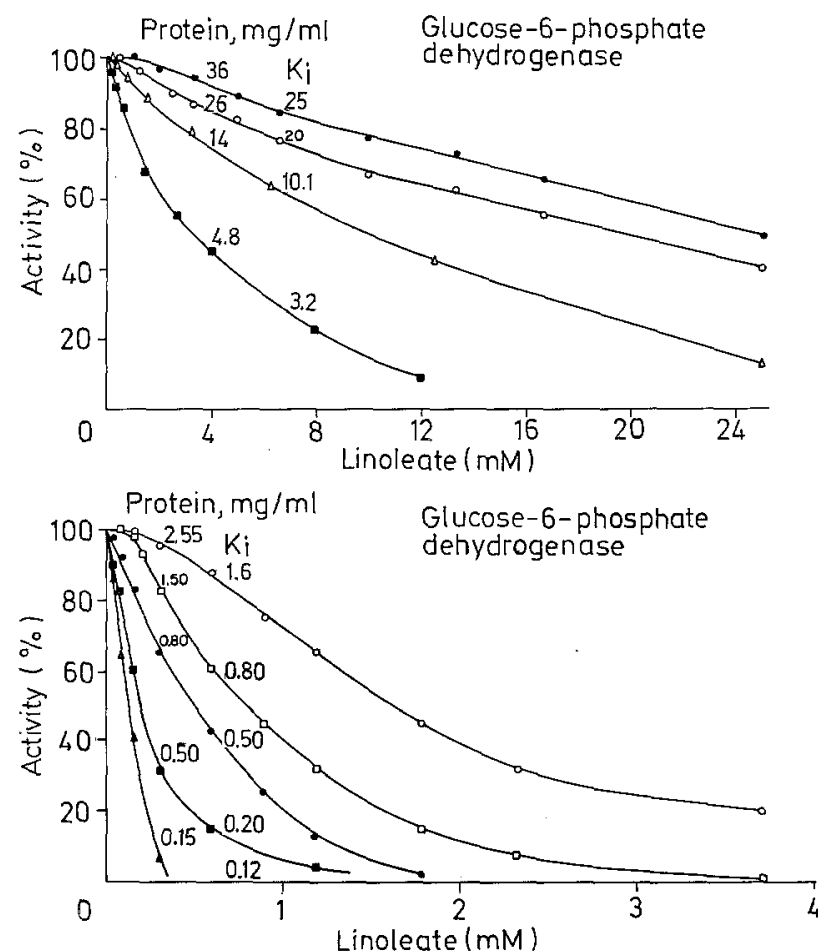

Fig. 1. Effect of linoleate on the activity of liver glucose6-phosphate dehydrogenase after incubation at varying cytoplasmic protein concentrations. Each curve, in the lower and upper section of the Figure, represents enzyme activity at a given dilution of the cytoplasmic fraction, assayed after $30 \mathrm{~min}$ of incubation at $37^{\circ} \mathrm{C}$ with increasing concentrations of potassium linoleate. The protein concentration at each dilution and the concentration of linoleate causing $50 \%$ inactivation at this dilution $\left(\mathbf{K}_{\mathbf{i}}\right)$ are indicated on the curves in two vertical columns. At each dilution, enzyme activity, measured after incubation with buffer solution instead of linoleate, was taken as $100 \%$. For further explanation see Methods

The determination of glucose-6-phosphate dehydrogenase activity, after preincubation with linoleate, required the dilution of the cytoplasmic fraction to a range convenient for the measurement of NADPH generation which contained approximately $0.1 \mathrm{mg} / \mathrm{ml}$ protein. It is highly unlikely that linoleate had any effect on the activity of enzyme after the incubation at $37^{\circ} \mathrm{C}$, since a $10 \mathrm{mg} / \mathrm{ml}$ albumin solution was used to dilute the incubation mixture. Albumin, at a concentration of 25 to $50 \mathrm{mg} / \mathrm{ml}$ prevented any deterioration in enzyme activity when added to the cytoplasmic fraction prior to the incubation with linoleate (Table 6). Albumin did not restore the activity of glucose-6-phosphate dehydrogenase when it was added after the incubation. It is of interest that linoleate had no effect on enzyme activity even when the molar ratio linoleate/albumin was between 4 and 2 .
This suggests competition for FFA by the second class binding sites on albumin which have an association constant of the order of $10^{-6}$, and can accomodate 4 to 6 molecules of FFA, but not competition by the

Table 6. Prevention by albumin of linoleate-induced inactivation of glucose-6-phosphate dehydrogenase

A series of tubes with liver cytoplasmic fraction, containing $1 \mathrm{mg} / \mathrm{ml}$ protein, was incubated for $30 \mathrm{~min}$ at $37^{\circ} \mathrm{C}$ with 1.44 umoles $/ \mathrm{ml}$ of potassium linoleate. Prior to the incubation, increasing amounts of FFA-poor bovine albumin were added as a concentrated solution. The final volume of the system was kept constant at $0.5 \mathrm{ml}$. After the incubation the mixture was diluted tenfold with $1 \%$ albumin solution and the enzyme activity determined. In. the calculation of molar ratios, the mol. wt. of albumin was taken as 65000 . The amount of FFA on the added albumin was less than $0.1 \mu$ mole $/ 50 \mathrm{mg}$ and was disregarded in the calculations, as was the proportion of linoleate bound to the proteins of the cytoplasmic fraction.

\begin{tabular}{lll}
$\begin{array}{l}\text { Albumin } \\
\mathrm{mg} / \mathrm{ml}\end{array}$ & $\begin{array}{l}\text { Molar ratio } \\
\text { linoleate/albumin }\end{array}$ & $\begin{array}{l}\text { Enzyme } \\
\text { activity, \% }\end{array}$ \\
\hline \multirow{3}{*}{0.0} & No Linoleate & 100 \\
& Linoleate & \\
0.0 & $\infty$ & 13 \\
$\mathbf{1 . 5 6}$ & 60 & 34 \\
$\mathbf{3 . 1 2}$ & 30 & 55 \\
6.25 & 15 & 70 \\
12.5 & 7.5 & 85 \\
25 & 3.75 & 96 \\
50 & 1.87 & 102 \\
\hline
\end{tabular}

third class binding sites, which have an association constant of the order of $10^{-3}$, and can bind a much larger number of molecules [20].

The dependence of the inhibitory effect of linoleate on the protein concentration of the cytoplasmic fraction was also noted with other enzymes. In each instance the loss of enzyme activity as a result of incubation with linoleate became gradually smaller when the protein concentration of the cytoplasmic fraction was increased. At a cytoplasmic protein concentration range of 22 to $30 \mathrm{mg} / \mathrm{ml}$, the $K_{i}$ for linoleate in the case of glucokinase, hexokinase, phosphofructokinase, pyruvate kinase, $\alpha$-glycerophosphate dehydrogenase, aldolase, and ATP-citrate lyase ranged from 3 to $9 \mathrm{mM}$. NAD-malate dehydrogenase was quite resistant to inactivation by linoleate, since at a protein concentration of $30 \mathrm{mg} / \mathrm{ml}$ almost no inactivation was noted under the conditions of this study (data not shown). Conversely, NADP-isocitrate dehydrogenase (Fig. 5) showed a marked susceptibility to linoleate. The $\mathrm{K}_{\mathrm{i}}$ of this enzyme for linoleate was $1.2 \mathrm{mM}$ at a protein concentration of $30 \mathrm{mg} / \mathrm{ml}$. These $K_{i}$ values were plotted for each enzyme as a function of cytoplasmic protein concentration (Fig. 2). Since a linear relationship was obtained up to $40 \mathrm{mg} / \mathrm{ml}$, the maximal in vitro used protein concentration an extrapolation of $\mathbf{K}_{\mathbf{i}}$ was carried out, assuming that the straight line relationship persists up to the intracellular cytoplasmic protein concentration of 90 to $110 \mathrm{mg} / \mathrm{ml}$. 
The interaction of the mitochondrial enzyme citrate synthetase with linoleate was also studied since it has been reported that its activity is decreased by FFA and that this may have a regulatory influence on the tricarboxylic acid cycle [6]. As with the cytoplasmic enzymes the effect of linoleate on citrate
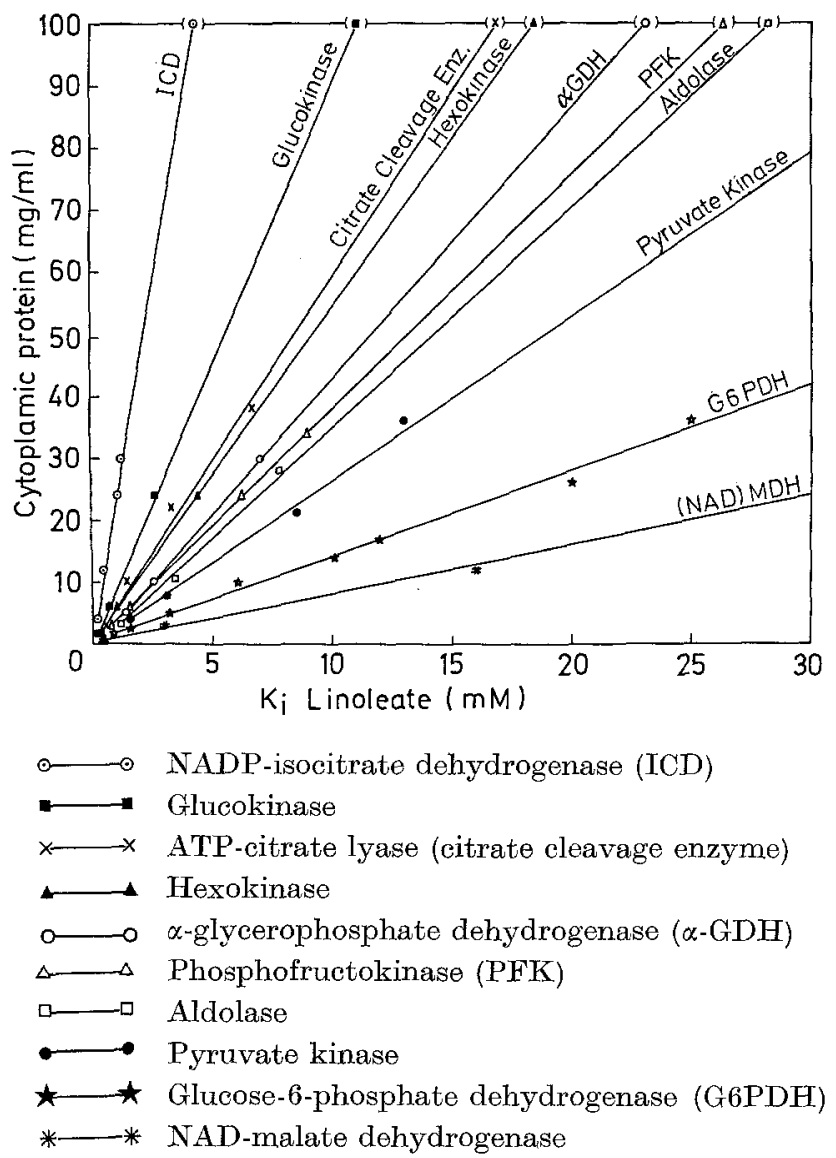

Fig. 2. Extrapolation of $\mathbf{K}_{\mathbf{i}}$ linoleate for several cytoplasmic liver enzymes as a function of cytoplasmic protein concentration. The $K_{i}$ values for each enzyme, obtained as illustrated for glucose-6-phosphate dehydrogenase in Fig. 1, were plotted against the respective protein concentration in the range of 1.5 to $40 \mathrm{mg} / \mathrm{ml}$. Assuming a linear relationship, the lines were extrapolated to $100 \mathrm{mg} / \mathrm{ml}$, the approximate protein concentration in liver cytoplasm (shown by marks in parentheses)

synthetase was dependent on the concentration of mitochondrial protein in the incubation system. A plot showing the dependence of $\mathbf{K}_{\mathbf{i}}$ linoleate for citrate synthetase on the mitochondrial protein concentration and its extrapolation to the assumed mitochondrial protein concentration in the intact cell is shown in Fig. 3.

CoA esters of fatty acids have also been reported to inhibit purified glucose-6-phosphate dehydrogenase [17] and acetyl-CoA carboxylase [5]. It was of interest to compare the characteristics of this inhibition with that due to linoleate in the cytoplasmic fraction system. Figs. 4 and 5 show that the extent of inhibition by palmityl-CoA was, similarly to linoleate, dependent on the protein concentration during the incubation. The $K_{i}$ linoleate and $K_{i}$ palmityl-CoA rose nearly 10-fold when the concentration of the cytoplasmic protein was increased from 3 to $24 \mathrm{mg} / \mathrm{ml}$. Both in the ease of glucose-6-phosphate dehydrogenase and acetyl-

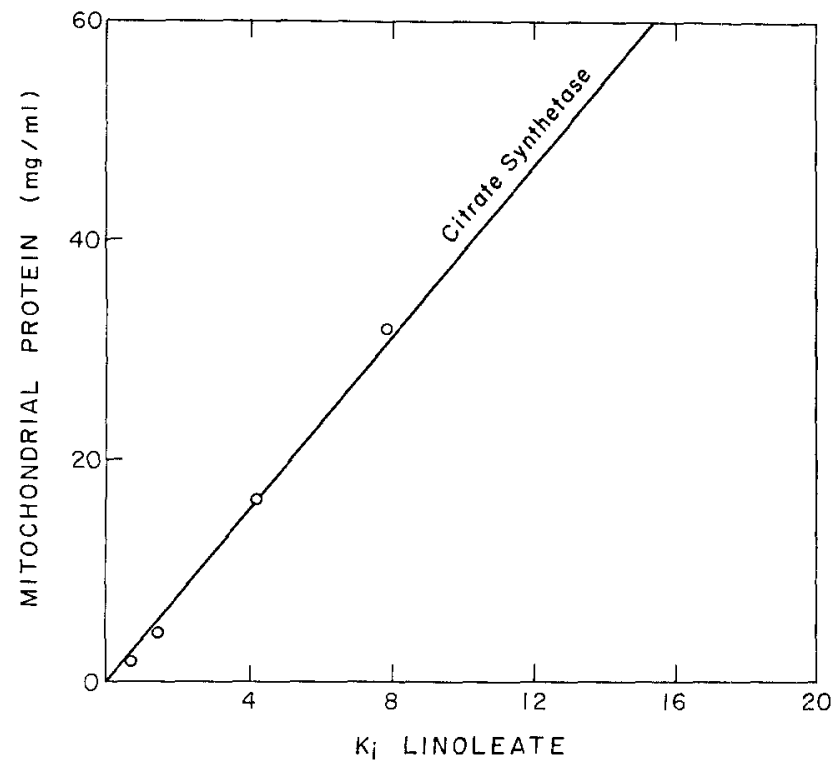

Fig. 3. Extrapolation of $K_{i}$ linoleate for liver citrate synthetase to intracellular mitochondrial protein concentrations. The $K_{i}$ values for citrate synthetase were plotted against protein concentration

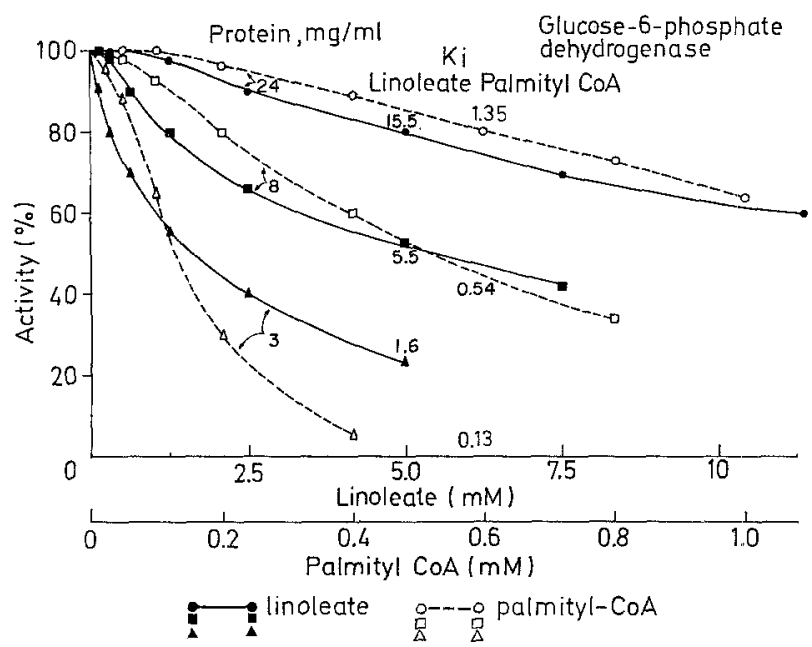

Fig. 4. Comparative effects of linoleate and palmityl-CoA on the activity of liver glucose-6-phosphate dehydrogenase. Three dilution sets of liver cytoplasmic fraction (protein concentration indicated in the first vertical column) were incubated for $30 \mathrm{~min}$ at $37^{\circ} \mathrm{C}$, with increasing concentrations of potassium linoleate or palmityl-CoA. The concentration of the respective inhibitor, which caused a $50 \%$ reduction in enzyme activity $\left(K_{i}\right)$ is indicated in the second vertical column 
CoA carboxylase, palmityl-CoA was a stronger inactivator than linoleate since at the same protein concentration a similar degree of enzyme activity reduction was produced at a palmityl-CoA concentration about one tenth that of linoleate. Acetyl-CoA carboxylase was considerably more sensitive than glucose-6-phosphate dehydrogenase to contact with linoleate or palmityl-CoA. $K_{i}$ linoleate and $K_{i}$ pal-

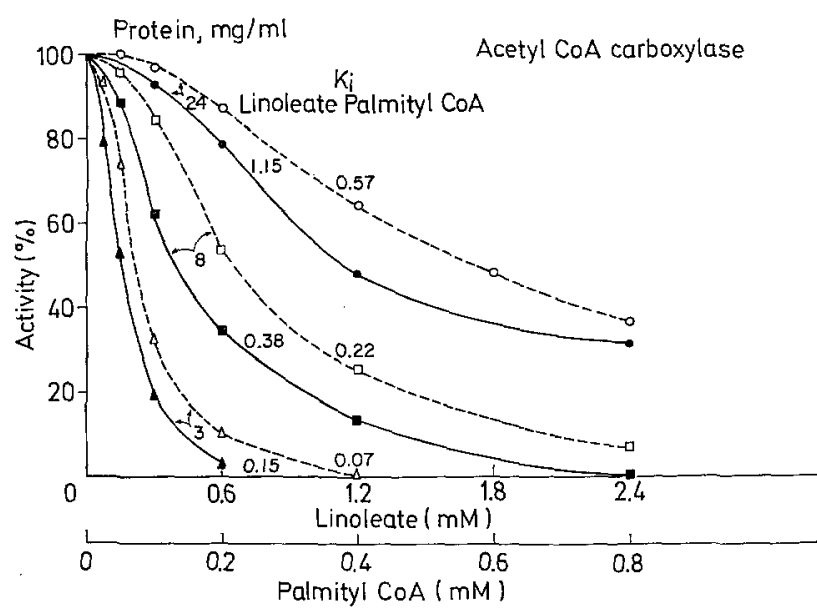

Fig. 5. Comparative effects of linoleate and palmityl-CoA on the activity of liver acetyl-CoA carboxylase. For explanations see Fig. 4

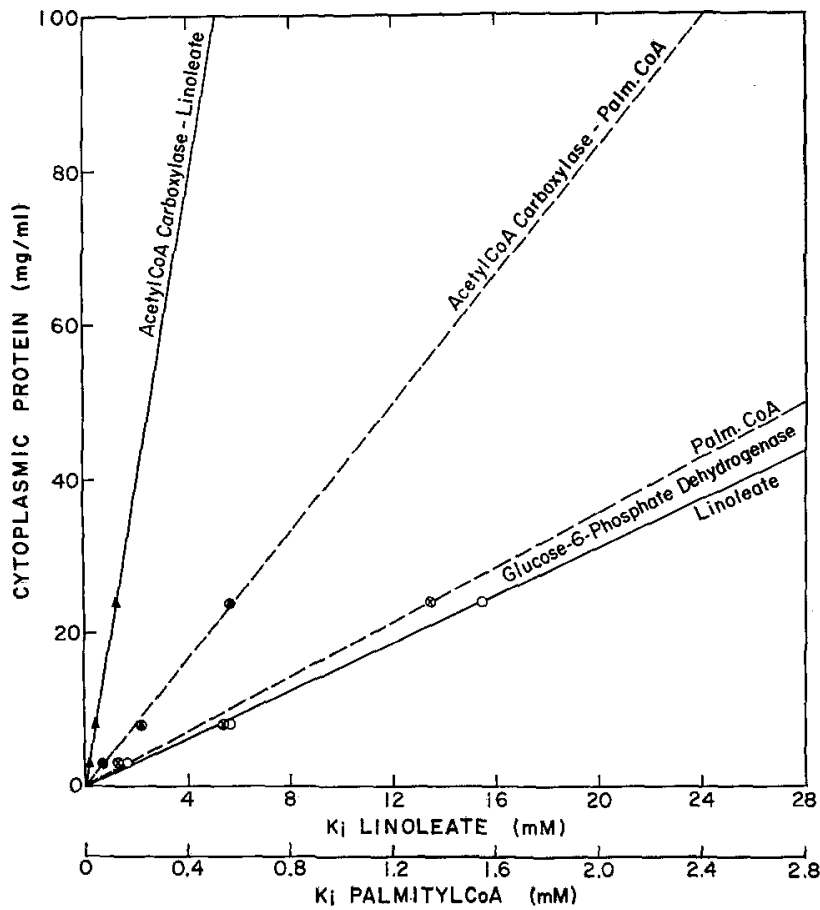

Fig. 6. Extrapolation of $K_{\mathbf{i}}$ linoleate and $K_{i}$ palmitylCoA for liver acetyl CoA carboxylase and glucose-6phosphate dehydrogenase to the intracellular cytoplasmic protein concentration. The $\mathbf{K}_{\mathbf{i}}$ values of linoleate and palmityl-CoA (Fig. 4 and 5) were plotted against the respective protein concentration. Assuming a linear relationship the lines were extrapolated to a protein concentration of $100 \mathrm{mg} / \mathrm{ml}$
mityl-CoA of acetyl-CoA carboxylase were 20 and 2 times lower, respectively, than in the case of glucose6-phosphate dehydrogenase.

The inhibitory effect of $1.2 \mathrm{mM}$ palmityl-CoA could be prevented by $25 \mathrm{mg} / \mathrm{ml}$ of albumin when added prior to the incubation to a cytoplasmic fraction containing $3 \mathrm{mg} / \mathrm{ml}$ protein, but it could not be reversed when the albumin was added after the incubation.

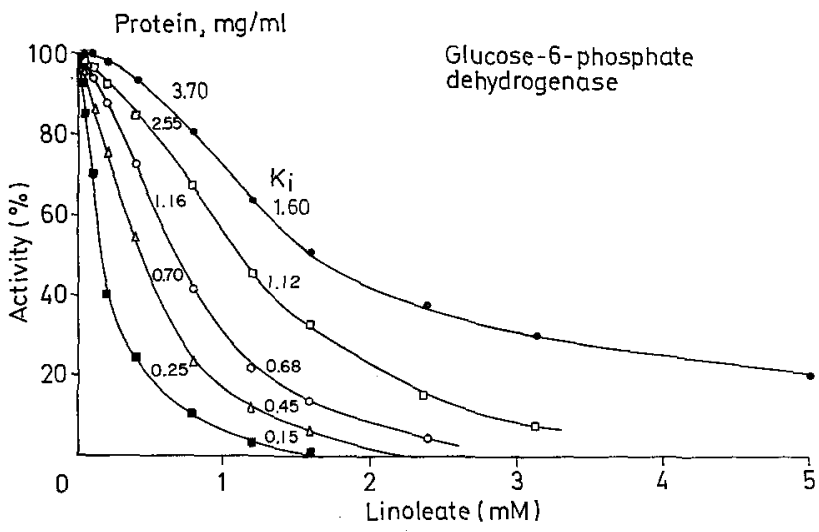

Fig. 7. Effect of linoleate on the activity of adipose tissue glucose-6-phosphate dehydrogenase. For explanations see legend to Fig. 1

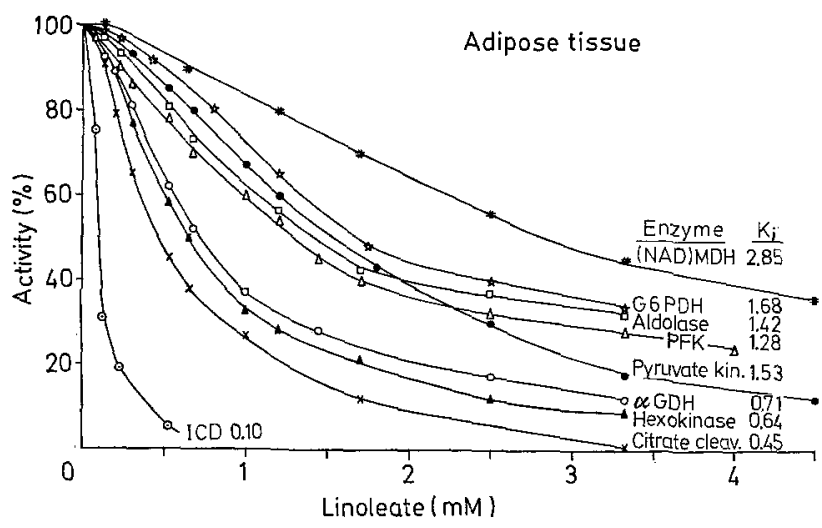

*-_ * NAD-malate dehydrogenase

$\star$ ઐ Glucose-6-phosphate dehydrogenase (G6PDH)

므 Aldolase

$\triangle$ Phosphofructokinase (PFK)

$\multimap$ NADP-isocitrate dehydrogenase (ICD)

$\longrightarrow$ Pyruvate kinase

$\multimap \alpha$-glycerophosphate dehydrogenase $(\alpha-G D H)$

- Hexokinase

$x \longrightarrow x$ ATP-citrate lyase (citrate cleavage enzyme)

Fig. 8. Effect of linoleate on the activity of several enzymes of adipose tissue. Enzyme activity was measured after incubation of the cytoplasmic fraction (protein concentration $3.6 \mathrm{mg} / \mathrm{ml}$ ) with increasing concentrations of potassium linoleate for $30 \mathrm{~min}$ at $37^{\circ} \mathrm{C}$. The concentration of linoleate effecting a $50 \%$ reduction in enzyme activity

$\left(K_{i}\right)$ is indicated next to the enzyme designation 
Dependence of the $K_{i}$ palmityl CoA for these two enzymes on the cytoplasmic protein concentration showed a linear relationship (Fig. 6). Assuming that the linearity persists, the $K_{i}$ was extrapolated to the cytoplasmic protein concentration in the intact cell.

The behavior of glucose-6-phosphate dehydrogenase activity of adipose tissue, when incubated with linoleate, was similar to that of the liver enzyme. Fig. 7 illustrates that the $K_{i}$ linoleate increases with increasing cytoplasmic protein concentrations. The span of protein concentrations used was small, since the cytoplasmic compartment of adipose tissue undergoes a considerable dilution during the homogenization.

Fig. 10 shows the $K_{i}$ linoleate for a group of adipose tissue enzymes incubated at a protein concentration of $3.6 \mathrm{mg} / \mathrm{ml}$. As with liver, the activity of NAD-malate dehydrogenase was most resistant and that of NADP-isocitrate dehydrogenase was most sensitive to linoleate. For most adipose tissue enzymes the magnitude of $K_{i}$ linoleate, relative to the cytoplasmic protein concentration, was in the same range as for the corresponding hepatic enzymes.

\section{Discussion}

This study points out that a physiologically meaningful interpretation of the interaction of FFA with enzymes should be expressed in terms of the concentration of FFA relative to the concentration of protein in the system. This is particularly critical when the effect of FFA is determined in tissue homogenates, since the concentration of protein is much lower than that within the cell, and as demonstrated here, cellular proteins exert a marked protective effect on the FFA-induced enzyme activity deterioration. The same criteria apply to the interaction of enzymes with CoA esters of long-chain fatty acids.

FFA interact with and denature numerous proteins at a high molar ratio to the protein $[8,9,24]$. This may be demonstrated in our experiments as well. Assuming arbitrarily that all cytoplasmic proteins bind FFA and that their average molecular weight is 60000 , the $K_{i}$ linoleate of $20 \mathrm{mM}$ recorded here for glucose-6-phosphate dehydrogenase, at a protein concentration of $30 \mathrm{mg} / \mathrm{ml}$, would mean the association of as many as 40 molecules of FFA per molecule of cytoplasmic protein. This is not compatible with an inhibition at a specific enzyme site. A gradual decline of function was produced during the contact of enzymes with FFA as evident from our observations that the loss of activity was irreversible after $30 \mathrm{~min}$ of incubation at $37^{\circ} \mathrm{C}$ even if the FFA were than removed by binding to albumin. Three conclusions may be drawn from these results: 1. contact with FFA results in a time-dependent, detergent-like association with multiple, non-specific sites on the enzyme molecule, causing inactivation rather than inhibition; 2. FFA are unlikely to be enzyme modifiers, since reversibility of inhibition constitutes one of the requisites of a homeostatic effector; 3 . presence of protein, other than the enzyme, influences the effect and protects the enzyme from inactivation by competitively binding FFA.

Taketa and Pogell [47] have reported that palmitylCoA inactivates numerous enzymes associated with unrelated metabolic pathways. With purified enzymes the molar ratio palmityl-CoA/protein, necessary to produce loss of activity, was quite large $[5,16,17,55]$. As a result, the regulatory importance of the inactivation of enzymes by FFA or their CoA esters was questioned [16, 33, 38, 47]. Our results strongly support this contention and extend its validity to physiological situations.

To demonstrate that the cellular FFA concentrations fall short of the $K_{i}$ values required for enzyme inactivation the in vitro determined $\mathbf{K}_{\mathbf{i}}$ values were extrapolated to the eytoplasmic protein content in the intact cell (Fig. 2). These $K_{\mathbf{i}}$ concentrations exceed the levels of total liver FFA (Table 2) at least by one order of magnitude. A similarly large discrepancy is found in the case of mitochondrial citrate synthetase (Fig. 3). Likewise, the $K_{i}$ concentration of palmityl-CoA for glucose-6-phosphate dehydrogenase and acetyl-CoA carboxylase at the intact cell cytoplasmic protein concentration (Fig. 6) exceeds by far the liver long-chain fatty acyl-CoA levels, reported to range from 0.05 to $0.10 \mu$ moles $/ g$ [49].

Furthermore, the effect of FFA on enzyme activity should be related not to the total cellular FFA content, but to the FFA concentration in the compartment in which the pertinent enzymes reside. Since only a small proportion of FFA resides in the cytoplasm (Tables 1 and 2), most of the tissue FFA are not available for interaction with the enzymes of glycolysis and lipogenesis which are localized to this compartment. The cytoplasmic FFA concentration, $0.1 \mathrm{mM}$ in the liver and $0.3 \mathrm{mM}$ in adipose tissue, is lower by as much as two orders of magnitude than the extrapolated $K_{i}$ concentration for glucokinase, phosphofructokinase, aldolase, pyruvate kinase, glucose-6-phosphate dehydrogenase or acetyl-CoA carboxylase (Figs. 2 and 6), enzymes which have been implicated to be controlled by FFA $[5,17,25,26,54]$.

Anti-insulin serum injection increased the FFA concentration in the liver considerably and in adipose tissue cytoplasm as well as in the mitochondria, particularly in the fasted rats (Tables 1 and 2). However, even these levels are markedly lower than the $\mathrm{K}_{\mathbf{i}}$ linoleate values obtained from the in vitro extrapolations. Absence of changes in the activity of most of liver and adipose tissue enzymes of rats injected with anti-insulin serum (Tables 4 and 5) corroborates the conclusion that these rises in FFA are not sufficient to inactivate enzymes in the intracellular milieu. 
Special consideration should be given to the selective decreases in the activity of liver and adipose tissue acetyl-CoA carboxylase, liver glucokinase and adipose tissue hexokinase observed in the acutely diabetic rats. The $\mathbf{K}_{\mathbf{i}}$ linoleate values for inactivation of these two enzymes, extrapolated for the intracellular protein concentration, were about 10 and $5 \mathrm{mM}$, respectively, in the same range as the $\mathrm{K}_{\mathrm{i}}$ for NADP-isocitrate dehydrogenase and ATP-citrate lyase, the activity of which was not affected by insulin deprivation. It appears therefore that glucokinase and acetyl-CoA carboxylase were affected by factors other than FFA. The decrease in liver glucokinase and adipose tissue hexokinase activity may perhaps be directly related to insulin inavailability since the activity of these enzymes was shown to be preserved in vitro by insulin $[4,36,37]$. The rapid decrease in acetyl-CoA carboxylase activity after insulin deprivation cannot be completely explained at present. It is unlikely that long-chain fatty acyl-CoA esters were involved. Levels of these CoA esters in diabetes or starvation amount to $0.1 \mu$ moles/g $[6,49]$, probably mainly confined to the mitochondria, whereas the extrapolated $K_{\mathbf{i}}$ palmityl-CoA for the cytoplasmic acetyl-CoA carboxylase, is $2.4 \mathrm{mM}$ (Fig. 6). The previously reported low $K_{i}$ values for long-chain fatty acyl-CoA inhibition of acetyl-CoA carboxylase [5] were based on an interaction with a purified enzyme preparation and cannot be used for physiological purposes. It is also pertinent that in triiodothyronine-treated rats, the activity of acetyl-CoA carboxylase activity and of other enzymes of lipogenesis in liver and adipose tissue was increased [13], despite the fact that in this condition the FFA and acyl-CoA levels rose two to three fold (E. Shafrir, unpublished observations).

It should be noted that the comparison between the tissue FFA levels and $\mathbf{K}_{\mathbf{i}}$ values determined in vitro are based on an arbitrary 30 min interaction of the cytoplasmic fraction with linoleate. Since this reaction is time-dependent, a more sustained contact with FFA such as in long-lasting starvation or diabetes, could theoretically lower the $\mathbf{K}_{\mathrm{i}}$ values. In this way, FFA might serve as a "physiological denaturant", which accelerates enzyme decay rates, as was suggested by Srere [44] and Eger-Neufeldt et al. [17]. However, the likelihood of such a role is doubtful because many unrelated enzymes would be thus indiscriminately affected, and because we have failed to note a decrease in the activity of most of the enzymes studied, in tissues of rats maintained for as long as $6 \mathrm{hrs}$ on anti-insulin serum.

On the contrary, there are cellular substances which may diminish the ability of FFA to inactivate enzymes in vivo. Enzyme cofactors and substrates, such as NAD, NADP, glucose, glucose-6-phosphate, oxaloacetate or citrate, were shown to confer protection against inactivation by FFA or acyl-CoA esters $[26,44,47]$. Thus, under in vivo conditions, the critical $K_{i}$ concentrations of FFA or acyl-CoA esters may be even higher than those calculated here.

Lack of decline in the maximal activity of most enzymes of glycolysis and lipogenesis, within 3 to $6 \mathrm{hrs}$ of acute insulin deprivation, and the relatively small increase in that of enzymes of gluconeogenesis must be contrasted to the prompt and marked elevation of serum glucose and other metabolic changes characteristic of this situation. This suggests that the rapid adjustments to insulin deprivation are not due to changes in enzyme concentration, but rather to the activation or deactivation of enzymes promptly responding to intracellular modifiers other than FFA. In agreement with this, increased liver gluconeogenesis was demonstrable within 3 hrs of food removal before any rise in the levels of FFA [45]. Changes in maximal activity of glycolytic, lipogenic and gluconeogenic enzymes in rats after total pancreatectomy [29], or anti-insulin serum injection [15] are detected later than would be expected if FFA inactivation was involved.

Finally, it should be noted that although FFA as such seem to be devoid of direct influence on enzymes in vivo, it is most probable that increased FFA oxidation does influence enzyme activity by causing changes in the levels of intracellular enzyme modifiers such as citrate, acetyl-CoA and NADH.

Acknowledgements. This work was supported in part by Grants AM-05077 and AM-15191 from the United States Public Health Service. We wish to thank Dr. G.F. Cahill, Jr., for his active interest and encouragement in this work and Dr. Peter Wright of the University of Indiana for the generous supply of anti-insulin serum. Mrs. Zenta Skulte and Vilma Lauris provided excellent technical assistance.

\section{References}

1. Ballard, F.J., Hanson, R.W., Leveille, G.A.: Phosphoenolpyruvate carboxykinase and the synthesis of glyceride glycerol from pyruvate in adipose tissue. J. biol. Chem. 242, 2476-2750 (1967)

2. Beinsenherz, G., Bücher, T., Garbade, K.H.: $\alpha$ Glycerophosphate dehydrogenase from rabbit muscle. Methods Enzymol. 1, 391-397 (1955)

3. Bezman-Tarcher, A.: Method for continuous intravenous infusion of large amounts of oleic acid into rats. J. Lipid Res. 10, $197-206$ (1969)

4. Borrebaek, B.: Adaptable hexokinase activity in epididymal adipose tissue studied in vivo and in vitro. Biochim. biophys. Acta (Amst.) 141, 221 - 230 (1967)

5. Bortz, W.M., Lynen, F.: The inhibition of acetylCoA carboxylase by long-chain acyl-CoA derivatives. Biochem. Z. 337, 505-509 (1963)

6. Brandes, R., Shapiro, B.: Inhibition of phosphatidic acid phosphatase by palmityl-CoA. Biochim. biophys. Acta (Amst.) 137, 202-204 (1967)

7. Bücher, T., Pfleiderer, G.: Pyruvate kinase from muscle. Methods Enzymol. 1, $435-440$ (1955)

8. Bull, H.B., Breese, K. : Binding of fatty acids by proteins. Arch. biochem. 120,303-308 (1967)

9. Bull, H.B., Breese, K.: Denaturation of proteins by fatty acids. Arch. biochem. 120, 309-315 (1967) 
10. Chang, H.C., Lane, M.D.: The enzymatic carboxylation of phosphoenolpyruvate. II. Purification and properties of liver mitochondrial phosphoenolpyruvate carboxykinase. J. biol. Chem. 241, 2413-2420 (1966)

11. Crofford, O.B., Renold, A.E.: Glucose uptake by incubated rat epididymal adipose tissue. J. biol. Chem. 240, $14-21(1965)$

12. Dawson, C.M., Hales, C.N.: The inhibition of rat liver glucokinase by palmityl-CoA. Biochim. biophys. Acta (Amst.) 176, 657-659 (1969)

13. Diamant, S., Gorin, E., Shafrir, E. : Enzyme activities related to fatty acid synthesis in liver and adipose tissue of rats treated with triiodothyronine. Europ. J. Biochem. 26, 553- 559 (1972)

14. Dole, V.P., Meinertz, H.: Microdetermination of long-chain fatty acids in plasma and tissues. J. biol. Chem. 235, 2595-2599 (1960)

15. Dolkart, R. F., Torok, E.E., Wright, P.H.: Hepatic enzyme activities in rats made diabetic with alloxan and with guinea pig anti-insulin serum. Diabetes $\mathbf{1 3}$, $78-82(1964)$

16. Dorsey, J.A., Porter, J.W.: The effect of palmityl Coenzyme A on pigeon liver fatty acid synthetase. J. biol. Chem. 243, 3512--3516 (1968)

17. Eger-Neufeldt, I., Teinzer, A., Weiss, L., Wieland, O. : Inhibition of glucose-6-phosphate dehydrogenase by long chain acyl-Coenzyme A. Biochem. biophys. Res. commun. 19, $43-48$ (1965)

18. Erfle, J.D., Sauer, F.: The inhibitory effects of acylCoenzyme A esters on the pyruvate and $\alpha$-oxogluterate dehydrogenase complexes. Biochim. biophys. Acta (Amst.) 178, 441-452 (1969)

19. Glock, G.E., McLean, P.: Further studies on the properties and assay of glucose-6-phosphate dehydrogenase and 6-phosphogluconate dehydrogenase of rat liver. Biochem. J., 55, 400-408 (1953)

20. Goodman, D.S.: The interaction of serum albumin with long chain fatty acid anions. J. Amer. chem. Soc. $80,3892-3898(1958)$

21. Gorin, E., Tal-Or, Z., Shafrir, E.: Glyceroneogenesis in adipose tissue of fasted, diabetic and triamcinolore treated rats. Europ. J. Biochem. 8, 370-375 (1969)

22. Kalkhoff, R.K., Kipnis, D.M.: Studies on the metabolic effects of acute insulin deficiency. I. Mechanism of impairment of hepatic fatty acid and protein synthesis. Diabetes 15, 433-450 (1966)

23. Kerpel, S., Shafrir, E., Shapiro, B.: Mechanism of fatty acid assimilation in adipose tissue. Biochim. biophys. Acta (Amst.) 46, 495-504 (1961)

24. Klotz, I.M. : Protein interactions. Chapter 8, Vol. 1B, p 773. In: The proteins (ed. H. Neurath). New York: Academic Press 1964

25. Korchak, N.M., Masoro, E.J.: Free fatty acids as lipogenic inhibitors. Biochim. biophys. Acta (Amst.) 84, 750-753 (1964)

26. Lea, M.A., Weber, G.: Role of enzymes in homeostasis. VIII. Inhibition of the activity of glycolytic enzymes by free fatty acids. J. biol. Chem. 243, 1096-1102 (1968)

27. Lowry, O.H., Rosebrough, N.J., Farr, A.L., Randall, R.J.: Protein measurement with the Folin phenol reagent. J. biol. Chem. 193, 265-275 (1951)

28. Matsuhashi, M., Matsuhashi, S., Numa, S., Lynen, F.: Zur Biosynthese der Fettsäuren. V. Die Acetyl-CoA Carboxylase aus Rattenleber und ihre Aktivierung durch Citronensëure. Biochem. Z. 340, 263-289 (1964)

29. Migliorini, R.H.: Early changes in the levels of glycolytic enzymes after total pancreatectomy in the rat. Biochim. biophys. Acta (Amst.) 244, 125-128 (1971)
30. Ochoa, S.: Crystalline condensing enzyme from pig heart. Methods Enzymol. 1, 685-694 (1955)

31. Ochoa, S.: Isocitric dehydrogenase system (TPN) from pig heart; "malic enzyme". Methods. Enzymol. $1,699-704 ; 739-748$ (1955)

32. Ochoa, S.: Malic dehydrogenase from pig heart. Methods Enzymol. 1, 735-739 (1955)

33. Pande, S.V., Mead, J.F.: Inhibition of enzyme activities by free fatty acids. J. biol. Chem. 243, $6180-$ $6185(1968)$

34. Reshef, L., Shapiro, B.: Fatty acid adsorption by liver and adipose tissue particles. Biochim. biophys. Acta (Amsti.) 98, 73-80 (1955)

35. Rose, H., Vaughan, M., Steinberg, D.: Utilization of fatty acids by rat liver slices as a function of medium concentration. Amer. J. Physiol. 206, 345-350 (1964)

36. Ruderman, N.B., Lauris, V., Herrera, M. G.: Insulin preservation of glucokinase activity in isolated perfused rat liver. Amer. J. Physiol. 212, 1169-1173 (1967)

37. Ruderman, N.B., Lauris, V.: Effect of acute insulin deprivation on rat liver glucokinase. Diabetes 17, $611-616$ (1968)

38. Ruderman, N.B., Toews, C.J., Shafrir, E.: Role of free fatty acids in glucose homeostasis. Arch. int. Med. 123, 299-313 (1969)

39. Shafrir, E., Lauris, V., Cahill, G.F.: Free fatty acid inhibition of glucose-6-phosphate dehydrogenase. Fed. Proc. 27, 331 (1968)

40. Sharma, C., Manjeshwar, R., Weinhouse, S.: Effects of diet and insulin on glucose-adenosine triphosphate phosphotransferases of rat liver. J. biol. Chem. 238, $3840-3845(1963)$

41. Spencer, A., Corman, L., Lowenstein, J.M.: Citrate and the conversion of earbohydrate into fat. Biochem. J. 93, 378-388 (1964)

42. Spolter, P.D., Adelman, R. C., Weinhouse, S.: Distinetive properties of native and carboxypeptidasetreated aldolases of rabbit muscle and liver. J. biol. Chem. 240, 1327-1337 (1965)

43. Srere, P. A.: Citrate-cleavage enzyme. Methods Enzymol, 5, $641-644$ (1962).

44. Srere, P.A.: Palmityl-Coenzyme A inhibition of the citrate-condensing enzyme. Biochim. biophys. Acta (Amst.) 106, 445-455 (1965)

45. Schimmel, R.J., Knobil, E.: Insulin, free fatty acids and stimulation of hepatic gluconeogenesis during: fasting. Amer. J. Physiol. 218, 1540-1547 (1970)

46. Swanson, M.A.: Phosphatases of liver. I. Glucose-6phosphatase. J. biol. Chem. 184, 647-659, 1950

47. Taketa, K., Pogell, B.M.: The effect of palmityl coenzyme A on glucose-6-phosphate dehydrogenase and other enzymes. J. biol. Chem. 241, 720-726 (1966)

48. Tani, H., Ogata, K.: Decrease of the hepatic ATP content and gluconeogenesis in ethionine-treated rats. Biochim. biophys. Acta (Amst.) 215, 264-272 (1970)

49. Tubbs, P.K., Garland, P.B.: Variations in tissue contents of coenzyme A thio esters and possible metabolic implications. Biochem. J. 93, 550-557 (1964)

50. Underwood, A.H., Newsholme, E. A. : Some properties of phosphofructokinase from kidney cortex and their relation to glucose metabolism. Biochem. J. 104, $296-299(\mathbf{1 9 6 7 )}$

51. Utter, M.F., Keech, D.B.: Pyruvate carboxylase. I. Nature of the reaction. J. biol. Chem. 238, 2603-2608 (1963)

52. Vaughan, M.: The production and release of glycerol by adipose tissue incubated in vitro. J. biol. Chem. 237, 3354-3358 (1962) 
53. Vijayvargiya, R., Singhal, R.L.: $\alpha$-glycerophosphate dehydrogenase inhibition in rat heart and adipose tissue. Proc. Soc. exper. Biol. (N.Y.) 133, 670-673 (1970)

54. Weber, G., Convery, H.J.H., Lea, M.A., Stamm, N. B.: Feedback inhibition of key glycolytic enzymes in liver: action of free fatty acids. Science 154, 1357$1360(1966)$

55. Wieland, O., Weiss, L., Eger-Neufeldt, I.: Hemmung der enzymatischen Citronensäuresynthese durch langkettige Acyl-thioester des Coenzym A. Biochem. Z. 339, 501-513 (1964)
56. Williamson, J.R., Browning, E.T., Scholz, R., Kreisberg, R.A., Fritz, I.B.: Inhibition of fatty acid stimulation of gluconeogenesis by $(+)$-decanoylcarnitine in perfused rat liver. Diabetes 17, 194-208 (1968)

Dr. E. Shafrir Dept. of Biochemistry

Hebrew University-Hadassah Medical School

P.O. Box 1172

Jerusalem, Israel 91000 